\title{
Knowledge and Attitude as Factors Affecting Regularity of Antenatal Care Visits
}

\author{
Titania, ${ }^{1}$ Elsa Pudji Setiawati, ${ }^{2}$ Hadi Susiarno ${ }^{3}$ \\ ${ }^{1}$ Faculty of Medicine Universitas Padjadjaran, Indonesia, ${ }^{2}$ Department of Public Health Faculty of \\ Medicine Universitas Padjadjaran,Bandung, Indonesia, ${ }^{3}$ Department of Obstetric and Gynecology \\ Faculty of Medicine Universitas Padjadjaran/Dr. Hasan Sadikin General Hospital, Bandung, \\ Indonesia
}

\begin{abstract}
Background: Maternal mortality ratio and infant mortality rate in Indonesia are still high and far from the Millennium Development Goals target. One of the solutions is by making regular antenatal care visits. Factors affecting antenatal care are knowledge and attitude. This study aimed to analyze the influence of knowledge and attitude about antenatal care toward regularity of antenatal care visit.

Methods: This analytic study was conducted by using the rapid survey through cross-sectional approach. The study population was pregnant women in Cipacing Village, Jatinangor Sub-district, with 55 samples. Questionnaires were distributed to evaluate the knowledge and attitude, and Kartu Menuju Sehat observation was conducted to investigate antenatal care visit.

Results: Out of 55 respondents, 26 had good knowledge, 25 had fair knowledge, and 4 had poor knowledge. Only 13 respondents had a good attitude level, while 42 had fair attitude, and none with poor attitude. As many as 46 respondents did antenatal care visits regularly, while 9 did not. Logistic regression analysis showed that knowledge and attitude had no significant influence towards regularity of antenatal care visit, with influence only approximately $2 \%$.

Conclusions: Knowledge, attitude, and regularity of antenatal care among respondents are good enough. Knowledge and attitude are not the dominant factors that affect the regularity of antenatal care visit. Thus a further study is needed to identify the other factors.
\end{abstract}

Keywords: Antenatal care, attitude, knowledge, regularity of visit

\section{Introduction}

Maternal mortality ratio (MMR) and Infant Mortality Rate (IMR) are two indicators of the Millennium Development Goals (MDGs), which are MDGs-4 and MDGs-5 respectively. ${ }^{1}$ Based on Indonesia Demographic and Health Survey (IDHS) 2007, MMR in Indonesia was 228 per 100,000 live births. ${ }^{2}$ The IDHS estimates the MMR will be reduced to 161 per 100,000 live births in 2015, which is far from the target of 102 per 100,000 live births., ${ }^{1,2}$ Hence, more effort is needed to reduce MMR. One of the solutions is by applying the Kesehatan Ibu dan Anak book, by making prenatal visits regularly. ${ }^{1,3}$

Antenatal Care (ANC) refers to a comprehensive approach to optimal medical care and psychosocial support that ideally begins prior to conception and ends with the onset of labor. ${ }^{4}$ Appropriate ANC can be achieved by making prenatal visit regularly and periodically, referring to the first visit (K1) and fourth visit (K4). ${ }^{5}$ Appropriate ANC aims to reduce the MMR and IMR, also the morbidity caused by complications in pregnancy. ${ }^{4}$

The minimum ANC visit is 4 visits during the whole pregnancy, which is one visit during trimester 1 (0-3 month of pregnancy), one visit during trimester 2 (4-6 month of pregnancy), and two visits during trimester 3 (7-9 month of pregnancy)., ${ }^{3,6}$ Each visit must meet the minimum standard that covers "7T". The "7T" includes height measurement, blood pressure measurement, fundal height measurement, tetanus toxoid injection, Fe tablet consumption, sexually transmitted disease tests, and consultation to prepare the referral. ${ }^{7}$

It was reported by Basic Health Research (Riskesdas) 2010, that the K1 in pregnant women in Indonesia was approximtely $92.7 \%$. Among them, about $72.3 \%$ has performed $\mathrm{K} 1$ during trimester 1 . Only about $64 \%$ pregnant

Correspondence: Titania, Faculty of Medicine, Universitas Padjadjaran, Jalan Raya Bandung-Sumedang Km.21, Jatinangor, Sumedang, Indonesia, Email: titan.titan12@gmail.com 
women has performed $\mathrm{K} 4$ in health facilities. Meanwhile, there is poor percentage of ANC component's performance in health facilities, that's only $19.9 \% 6$ In fact, the appropriate ANC visit can help to quickly resolve the problems that arise in pregnancy, such as eclampsia, abortus, hemorrhage, and infection which are the major cause of maternal mortality in Indonesia. ${ }^{2,3}$

There are many factors that affect practice, such as knowledge, attitude, health facilities, and infrastructure. ${ }^{8}$ Hence, the regularity of ANC visits (practice), can be affected by knowledge and attitude. A previous study in Malang 9 showed that there is a positive correlation between knowledge and attitude toward the regularity of ANC visits. On the contratry, another study in Sragen showed there is no relationship between knowledge and ANC visits. Knowledge and attitude only affect ANC visits by $28.3 \% .{ }^{10}$ Therefore, this study was conducted to analyze the influence of knowledge and attitude about ANC toward regularity of ANC visits.

\section{Methods}

This was an analytic study through crosssectional approach, which was conducted in Cipacing Village, Jatinangor Sub-district, Sumedang Regency, Bandung, from OctoberNovember 2012. Cipacing Village was chosen because the discrepancy between $\mathrm{K} 1$ and K4 was $5.52 \%$. Besides, Cipacing Village has the most number of pregnant women in Jatinangor; also it is not difficult to access.

The population was pregnant women in Cipacing Village. Samples were selected through inclusion and exclusion criteria. The inclusion criteria were residents of Cipacing Village, willing to participate and sign the informed consent, and had gestational age of at least 3 months at the time the sample was taken. The exclusion criteria were the respondents that could not finish the questionnaire at the time of data collection.

Among 120 pregnant women in Cipacing Village, 107 women met the inclusion criteria.

Table 1 Characteristics of Respondent

\begin{tabular}{|c|c|c|c|}
\hline Variable & Category & Frequency (n) & Percentage (\%) \\
\hline \multirow[t]{5}{*}{ Age (year) } & $<20$ & 4 & 7.3 \\
\hline & $20-35$ & 47 & 85.5 \\
\hline & $>35$ & 4 & 7.3 \\
\hline & Mean (SD) & $28.55(5.77)$ & \\
\hline & Range & $16-43$ & \\
\hline \multirow[t]{2}{*}{ Occupation } & Not work & 35 & 63.6 \\
\hline & Work & 20 & 36.4 \\
\hline \multirow[t]{2}{*}{ Family Income } & $<\operatorname{Rp} 1,058,978$ & 26 & 47.3 \\
\hline & $\geq \operatorname{Rp} 1,058,978$ & 29 & 52.7 \\
\hline \multirow[t]{5}{*}{ Education } & None & 0 & 0 \\
\hline & Primary School & 5 & 9.1 \\
\hline & Junior High School & 22 & 40 \\
\hline & Senior High School & 23 & 41.8 \\
\hline & College & 5 & 9.1 \\
\hline \multirow[t]{5}{*}{ Parity } & 0 & 21 & 38.2 \\
\hline & $1-4$ & 32 & 58.2 \\
\hline & $>4$ & 2 & 3.6 \\
\hline & Mean (SD) & $1.2(1.325)$ & \\
\hline & Range & $0-6$ & \\
\hline
\end{tabular}


The minimum sample was calculated by using the Slovin formula because the number of the target population was known, giving a minimum sample of 51.69. As many as 55 samples were taken to anticipate the loss of participants in the course of the study, by using the simple random sampling method.

The questionnaire was used to investigate the independent variables, which were knowledge and attitude. The women who consented were asked to fill out the structured questionnaire, which was developed by the researcher based on the Kesehatan Ibu dan Anak book, in Indonesian language. Interviews by using the questionnaire were conducted for women who could not read. Then, the respondents would ask them to show their Kartu Menuju Sehat (KMS) to assess the regularity of ANC visits.

To ensure internal consistency, a reliability test for the knowledge and attitude scale was performed, and given the Cronbach's Alpha value of 0.634 and 0.859 respectively. The result showed that the questionnaires were realiable, because they had Cronbach's alfa $>0.6$. The validity test was carried out by using the corrected item-total correlation score. There were 6 knowledge's questions and 2 attitude's questions that had $p$-value $<0.3$, therefore, they must be excluded from the questionnaire. Pretesting of the questionnaire was conducted to 30 pregnant women in Hegarmanah Village and Cikeruh Village, Jatinangor Sub-district.

The respondent's data, including name, age, occupation, income, last educational status, and parity were collected. The questions of knowledge were divided into several sections, which were knowledge about definition, purpose, frequency, components of ANC visit, nutrition in pregnant woman, counseling, and high-risk pregnancy. The scoring used the Guttmann scale, which are one point for the right answer and zero point for the wrong answer. The questions of attitude consisted of positive and negative statements. The scoring

Table 2 Distribution of ANC Knowledge Based on Characteristics of Respondent

\begin{tabular}{|c|c|c|c|c|c|c|}
\hline & & & \multicolumn{4}{|c|}{ Level of Knowledge } \\
\hline & & & Poor & Fair & Good & Total \\
\hline \multirow{20}{*}{$\begin{array}{l}\text { Respondents } \\
\text { Characteristics }\end{array}$} & \multirow[t]{4}{*}{ Age (year) } & $<20$ & 1 & 1 & 2 & 4 \\
\hline & & $20-35$ & 3 & 23 & 21 & 47 \\
\hline & & $>35$ & - & 1 & 3 & 4 \\
\hline & & Total & 4 & 25 & 26 & 55 \\
\hline & \multirow[t]{3}{*}{ Occupation } & Not Work & 3 & 16 & 16 & 35 \\
\hline & & Work & 1 & 9 & 10 & 20 \\
\hline & & Total & 4 & 25 & 26 & 55 \\
\hline & \multirow[t]{3}{*}{ Family Income } & $<\operatorname{Rp} 1,058,978$ & 3 & 12 & 11 & 26 \\
\hline & & $\geq \operatorname{Rp} 1,058,978$ & 1 & 13 & 15 & 29 \\
\hline & & Total & 4 & 25 & 26 & 55 \\
\hline & \multirow[t]{6}{*}{ Education } & None & - & - & - & - \\
\hline & & Primary School & 1 & 1 & 3 & 5 \\
\hline & & Junior High School & 3 & 10 & 9 & 22 \\
\hline & & Senior High School & - & 11 & 12 & 23 \\
\hline & & College & - & 3 & 2 & 5 \\
\hline & & Total & 4 & 25 & 26 & 55 \\
\hline & \multirow[t]{4}{*}{ Parity } & 0 & 4 & 11 & 6 & 21 \\
\hline & & $1-4$ & - & 13 & 19 & 32 \\
\hline & & $>4$ & - & 1 & 1 & 2 \\
\hline & & Total & 4 & 25 & 26 & 55 \\
\hline
\end{tabular}


Table 3 Distribution of Right and Wrong Answers in Each Question of ANC Knowledge Questionnaire

\begin{tabular}{|c|c|c|c|c|c|}
\hline \multirow{2}{*}{ No. } & \multirow{2}{*}{ Question } & \multicolumn{2}{|c|}{ Right } & \multicolumn{2}{|c|}{ Wrong } \\
\hline & & $\mathrm{N}$ & $\%$ & $\mathrm{~N}$ & $\%$ \\
\hline 1. & $\begin{array}{l}\text { Know whether the antenatal care should be performed before } \\
3 \text { months of gestational age }\end{array}$ & 31 & 56.4 & 24 & 43.6 \\
\hline 2. & Know whether pregnant women need vitamin supplements & 55 & 100 & - & - \\
\hline 3. & $\begin{array}{l}\text { Know whether pregnant women are allowed to consume } \\
\text { herbal drinks }\end{array}$ & 34 & 61.8 & 21 & 38.2 \\
\hline 4. & $\begin{array}{l}\text { Know whether a pregnant woman should do antenatal care } \\
\text { at least four times during the whole complete pregnancy ( } 9 \\
\text { months) }\end{array}$ & 32 & 58.2 & 23 & 41.8 \\
\hline 5 & $\begin{array}{l}\text { Know whether a pregnant woman can do antenatal care in the } \\
\text { village clinic }\end{array}$ & 47 & 85.5 & 8 & 14.5 \\
\hline 6. & $\begin{array}{l}\text { Know whether a pregnant woman should have tetanus toxoid } \\
\text { (TT) immunization }\end{array}$ & 47 & 85.5 & 8 & 14.5 \\
\hline 7. & $\begin{array}{l}\text { Know whether it necessary for pregnant woman to reduce } \\
\text { their activity during pregnancy }\end{array}$ & 48 & 87.3 & 7 & 12.7 \\
\hline 8. & $\begin{array}{l}\text { Know whether a pregnant woman went to the doctor / } \\
\text { midwife only when experiencing danger sign }\end{array}$ & 26 & 47.3 & 29 & 52.7 \\
\hline 9. & $\begin{array}{l}\text { Know whether high blood pressure can affect the growth of } \\
\text { the baby during pregnancy }\end{array}$ & 47 & 85.5 & 8 & 14.5 \\
\hline 10. & $\begin{array}{l}\text { Know whether a pregnant woman need a consultation with } \\
\text { physician or midwife to prepare the birth }\end{array}$ & 50 & 90.9 & 5 & 9.1 \\
\hline 11. & $\begin{array}{l}\text { Knowing at least one test that should be done when attending } \\
\text { antenatal checkup }\end{array}$ & 50 & 90.9 & 5 & 9.1 \\
\hline 12. & Knowing at least one danger sign during pregnancy & 55 & 100 & - & - \\
\hline
\end{tabular}

used the Likert scale, ranging from 1-4 points. Then, the scores of knowledge and attitude in the questionnaire were grouped into good, fair, and poor level; the scores were $>80 \%$, $60-80 \%$, and $<60 \%$ respectively. The number of ANC visits in KMS was grouped into regular and irregular visits. A regular ANC visit must have a number of ANC attendance in KMS that is in accordance with the supposed frequency for the respective gestational age.

Data analysis was processed by using SPSS version 15.0. The univariate analysis was performed by using frequencies, percentages, means and standard deviations. While the bivariate and multivariate analyseswere performed by using chi-square and logistic regression respectively. Chi-square was used because the variables had an ordinal scale and not in pair. Logistic regression was performed to test the hypothesis, which is to analyze the influence of knowledge and attitude about ANC toward regularity of ANC visits. Logistic regression was used because this study had multivariables and the dependent variable had a categoric scale. A test was carried out to evaluate the feasibility of the logistic regression.

The ethical approval to conduct the study was obtained from the Medical Research Ethics Committee of the Faculty of Medicine, Universitas Padjadjaran, Number.....

\section{Results}

A total of 55 pregnant women agreed to participate in this study. The characteristics of respondents were shown by age group; the majority of the respondents were 20-35 years, as many as 47 persons $(85.5 \%)$. There were high-risk pregnant women who were aged $<20$ years, and aged $>35$ years as many as 4 persons $(7.3 \%)$ respectively. Most of the respondents who did not work were 35 persons (63.6\%). As many as 29 persons (52.7\%) had a family income $\geq \mathrm{Rp} 1,058,978$. Among 55 respondents, who were mostly senior high school graduates were 23 persons $(41.8 \%), 22$ persons $(40 \%)$ were junior high school graduates, 5 persons (9.1\%) were primary school graduates, and the rest were college graduates. Most of the 
Table 4 Frequency Distribution of Attitude of Respondents Based on Characteristics of the Respondents

\begin{tabular}{|c|c|c|c|c|c|c|}
\hline & & & & Leve & ttitude & \\
\hline & & & Poor & Fair & Good & Total \\
\hline Respondents & Age (year) & $<20$ & - & 4 & 0 & 4 \\
\hline haracteristics & & $20-35$ & - & 36 & 11 & 47 \\
\hline & & $>35$ & - & 2 & 2 & 4 \\
\hline & & Total & - & 42 & 13 & 55 \\
\hline & Occupation & Not Work & - & 30 & 5 & 35 \\
\hline & & Work & - & 12 & 8 & 20 \\
\hline & & Total & - & 42 & 13 & 55 \\
\hline & Family Income & $<\mathrm{Rp} 1,058,978$ & - & 21 & 5 & 26 \\
\hline & & $\geq \mathrm{Rp} 1,058,978$ & - & 21 & 8 & 29 \\
\hline & & Total & - & 42 & 13 & 55 \\
\hline & Education & None & - & 0 & 0 & 0 \\
\hline & & Primary School & - & 4 & 1 & 5 \\
\hline & & Junior High School & - & 22 & 0 & 22 \\
\hline & & Senior High School & - & 15 & 8 & 23 \\
\hline & & College & - & 1 & 4 & 5 \\
\hline & & Total & - & 42 & 13 & 55 \\
\hline & Parity & 0 & - & 18 & 3 & 21 \\
\hline & & $1-4$ & - & 22 & 10 & 32 \\
\hline & & $>4$ & - & 2 & 0 & 2 \\
\hline & & Total & - & 42 & 13 & 55 \\
\hline
\end{tabular}

respondents ( 32 persons) had $1-4$ parities, 21 respondents $(38.2 \%)$ never gave birth, and the rest had $>4$ parity (Table 1 ).

The majority of pregnant women $(47.3 \%)$ had good level of knowledge. Only 7.3\% pregnant women had poor level of knowledge whereas $45.5 \%$ had fair level of knowledge. The distribution of knowledge was based on the respondent's characteristics (Table 2).

The respondents' level of knowledge were distributed both in women aged 20-35 years and in women who did not work. Respondents with poor knowledge were mainly junior high school graduates, had family income $<$ Rp1,058,978, and never gave birth. Meanwhile, most of the respondents with fair and good knowledge were senior high school graduates, had family income $\geq \mathrm{Rp} 1,058,978$, and had 1-4 parities (Table 2).

Furthermore, from the distribution of correct and incorrect answers by the respondents, a total of 47 respondents
$(85.5 \%)$ knew that pregnant women should have tetanus toxoid (TT) immunization. All respondents knew that pregnant women need vitamin supplements as well as knew at least one danger sign during pregnancy. As many as 50 respondents $(90.9 \%)$ knew at least there was one test that should be carried out during antenatal care. However, only 31 respondents (56.4\%) were aware that antenatal care must be performed before 3 months of gestational age. About $58.2 \%$ (32 respondents) knew that the antenatal care must be carried out at least 4 times during the whole course of pregnancy. Only 26 respondents (47.3\%) knew that antenatal care was not only done when they were having danger signs only (Table 3 ).

The frequency distribution of attitude based on maternal characteristics showed, the majority of respondents attitudes were fair as many as 42 people $(76.4 \%)$. Only 13 people $(23.6 \%)$ had good level of attitude and no respondent had a poor attitude. (Table 4). 
Table 5 Relationship between Knowledge and Regularity of ANC Visits

\begin{tabular}{lllcc}
\hline & & \multicolumn{2}{c}{ Regularity of visits } \\
\cline { 3 - 5 } Level of knowledge & Poor & Count & 1 & Regular \\
\cline { 3 - 4 } & \multirow{3}{*}{ Fair } & Expected Count & .7 & 3 \\
& & Count & 4 & 3.3 \\
& Good & Expected Count & 4.1 & 21 \\
& & Count & 4 & 20.9 \\
& & Expected Count & 4.3 & 22 \\
& & & 21.7 \\
\hline
\end{tabular}

Table 6 Relationship between Attitude and Regularity of ANC Visits

\begin{tabular}{lllcc}
\hline & & \multicolumn{2}{c}{ Regularity of Visit } \\
\cline { 3 - 4 } & & & Irregular & Regular \\
\hline Level of Attitude & Fair & Count & 8 & 34 \\
& & Expected Count & 6.9 & 35.1 \\
& \multirow{2}{*}{ Good } & Count & 1 & 12 \\
& & Expected Count & 2.1 & 10.9 \\
\hline
\end{tabular}

Moreover, the majority of the respondents with good and fair attitude was aged 20-35 years, did not work, and had 1-4 parity. Respondents with fair level of attitude were mainly junior high school graduates. Meanwhile, the respondents with good attitude were mainly senior high school graduates and had family income $\geq$ Rp1,058,978 (Table 4).

Based on the observation of frequency of the ANC visits, the majority of the respondents as many as 46 persons (83.6\%) carried out ANC visits regularly. A total of nine persons (16.4\%) had irregular ANC visits. Bivariate analysis was conducted by using chi-square test to determine the relationship between knowledge and regularity of ANC visits (Table 5).

Furthermore, the majority of the respondents on every level of knowledge carried out ANC regularly. There were four cells $(66.7 \%)$ that had expected count less than five, which means that the data were not qualified to be analyzed with chi-square. After the cells were merged and re-analyzed by using the chi-square, there were two cells $(50 \%)$ that had expected count value less than five. Hence, the alternative test which was the Fisher exact test was used. The result showed p-value (significancy score) 1.00, which was less than 0.05 . This score means that the relationship between knowledge and regularity of ANC visits was not significant.

The analysis of the relationship between attitude and regularity of ANC visits was performed by using chi-square test. Based on the data and results of the statistical calculations, the respondents with fair level of attitude mostly had regular ANC visits, were as many as 34 people. Since there was one cell (25\%) with expected count value less than five, the Fisher exact test was used as an alternative test. The result showed p-value (significancy score) 0.669 , which was more than 0.05 . This score indicated that there was no significant relationship between attitude and regularity of ANC visits (Table 6).

The logistic regression analysis was performed to determine the influence of knowledge and attitude towards regularity of ANC visits. Normality test was not required because it had binary form of data, but it was necessary to test the feasibility of a logistic regression model (overall model fit). The feasibility test was conducted by using the likelihood test and Hosmer and Lemeshow's test Goodness of Fit. Based on the test result, this study was feasible to use the logistic regression.

The result of the logistic regression analysis showed p-value (significancy score) 0.761 , which was more than 0.05 . This score indicated that the knowledge and attitude 
as one unit did not significantly affect the regularity of ANC visits. Meanwhile, the Cox and Snell R Square test showed value 0.021, which means that the regularity of visits could be explained by knowledge and attitude only about $2.1 \%$, while the remaining (97.9\%) could be explained by other variables that were not used in this study.

\section{Discussions}

This study aimed to determine the distribution of knowledge, attitude, and regularity of ANC visits, as well as to analyze the effect of knowledge and attitudes towards regularity of ANC visits. The result showed that most of the respondents had good and fair knowledge. The majority of the respondents with good knowledge was senior high scool graduates and had a family income $\geq \mathrm{Rp} 1,058,978$. Referring to the theory, knowledge is influenced by several factors such as education and economy ${ }^{11}$ In this study, the attitude was mostly distributed at the fair level of attitude. This result might be due to the majority of the respondents also had fair level of knowledge. This referred to the theory of Notoatmodjo ${ }^{8}$, which state that the knowledge can built the attitude.

Based on this study, there were 46 respondents (83.6\%) who performed ANCs visit regularly. From the test results of bivariate statistics, there was neither significant relationship between knowledge and regularity of ANC visits nor between attitudes towards regularity of ANC visits. Meanwhile, based on the result of logistic regression, there was no significant influence of knowledge and attitude towards regularity of ANC visits. Knowledge and attitude only gave $2.1 \%$ influence toward regularity of ANC visits, while another $97.9 \%$ was given by other factors that were not examined in this study.

This result was contradictive with the theory of Notoatmodjo ${ }^{8}$, which stated that practice is preceded by attitude, while attitude is built by knowledge. This indicates that knowledge and attitude are not the only factors that affect the regularity of ANC visits. Practice (action), which in this case was the regularity of visits, is influenced by other factors, such as the facilities and infrastructure that support the attitude become the practice. ${ }^{8}$

Other external factors that could affect the regularity of ANC visits were the levels of activities and time that were owned by the respondent, or the distance that was required for reaching health facilities. Iksaruddin ${ }^{12}$ in his study results reported that the access time is associated with ANC visits. Maternal characteristics as the confounding factors in this study such as age, occupation, income, education level, and gestation could be the factors that affected the regularity of ANC visits. However, it was not analyzed in this study.

This study had limitations that could affect the result, such as data inconsistency. The pregnant women data from Puskesmas were inconsistent with the actual number of pregnant women in Cipacing Village. To overcome this problem, the researcher had re-checked the data of pregnant women to the local midwife in Cipacing Village.

The conclusions are, the majority of pregnant women has a good level of knowledge, fair level of attitude, and attends ANC visits regularly. There is no significant effect of knowledge and attitude towards regularity of ANC visits $(p=0.570)$. Further research is needed to identify other factors that influence the regularity of ANC visits. The minimal influence of knowledge and attitude towards regularity of ANC visits can be a reference for the local health government in planning an effective and efficient way to reduce MMR and IMR, and obviously counseling for increasing knowledge alone is not enough.

\section{References}

1. Kementerian Kesehatan Republik Indonesia. Capai target MDG's demi terwujudnya derajat kesehatan masyarakat yang tinggi. Makassar: Kementerian Kesehatan Republik Indonesia; 2012 [downloaded in 15 April 2012]; Available at: $\quad$ http://www.depkes.go.id/index. $\mathrm{php} /$ berita/press-release/1802-capaitarget-mdgs-demi-terwujudnya-derajatkesehatan-masyarakat-yang-tinggi.html.

2. Hernawati I. Analisis kematian ibu di Indonesia tahun 2010. In: Direktorat Jenderal Bina Gizi dan Kesehatan Ibu dan Anak, editor. Jakarta: Ministry of Health Republic of Indonesia; 2011.

3. Kementerian Kesehatan Republik Indonesia. Buku kesehatan ibu dan anak. Jakarta: Kementerian Kesehatan Republik Indonesia; 2011.

4. Cunningham F, Leveno K, Bloom S, Hauth J, Rouse D, Spong C. Williams obstetrics. 23rd ed. New York: McGraw-Hill; 2009. p. 189-237.

5. Kementerian Kesehatan Republik Indonesia. Variabel dan indikator program 
gizi dan KIA. Jakarta: Kementerian Kesehatan Republik Indonesia; [cited 2012 April 15]; Available at: http:// www.gizikia.depkes.go.id/wp-content/ uploads/downloads/2012/04/DefinisiVariabel-SIM-Gizi-KIA-Terintegrasi.pdf.

6. Badan Penelitian dan Pengembangan Kesehatan. Riset kesehatan dasar (Riskesdas) 2010. Jakarta: Kementerian Kesehatan Republik Indonesia; 2010.

7. Prawirohardjo S. Pelayanan kesehatan maternal dan neonatal. Jakarta: Yayasan Bina Pustaka - Sarwono Prawirohardjo; 2002.

8. Notoatmodjo S. Ilmu perilaku kesehatan. Jakarta: Rineka Cipta; 2010.

9. Candra S, Praptono MGH, Dewi NI. Hubungan tingkat pengetahuan dan sikap tentang antenatal care dengan keteraturan kunjungan antenatal care pada ibu postpartum di posyandu wilayah kerja Puskesmas Arjowinangun Kota Malang [Thesis]. Malang; Universitas Brawijaya; 2008.

10. Asihani D. Hubungan antara pengetahuan dan sikap ibu hamil tentang antenatal care dengan kunjungan pemeriksaan kehamilan di Rumah Bersalin Permata Bunda Sragen [Thesis]. Surakarta: Universitas Sebelas Maret; 2009.

11. Notoadmodjo S. Pendidikan dan perilaku kesehatan. Jakarta: Rineka Cipta; 2003.

12. Iksaruddin. Hubungan antara pengetahuan ibu hamil tentang pelayanan antenatal dengan kunjungan periksa hamil di Puskesmas Pintas Tuo Kabupatan Tebo Provinsi Jambi [Minor Thesis]. Semarang: Universitas Diponegoro; 2009. 